\title{
Tissue Lipids in Acute Acrylamide Intoxicated Rats
}

\author{
Y.S. HUANG, P. WONG, D. BLACHE, A. BARBEAU, J. DAVIGNON
}

\begin{abstract}
A preliminary survey of tissue lipid composition in acrylamide intoxicated rats is reported. The animals were injected intraperitoneally with acrylamide $50 \mathrm{mg} / \mathrm{kg}$ body weight per day for 10 days. Liver cholesterol, mainly in the ester fraction, was decreased in treated rats. When fatty acid composition of liver cholesterol esters was examined, the proportions of linoleate and stearate were found to be decreased and were compensated by the increase of palmitate. Atrophy of epididymal fat pad resulted in severe triglyceride depletion and a relative increase in the proportion of phospholipids and cholesterol. There was also a reduction of linoleate, palmitate and palmitoleate in triglycerides and phospholipids of this tissue. There were, however, only minor changes in the fatty acid profile of the sciatic nerve.
\end{abstract}

RÉSUMÉ: Nous rapportons une étude préliminaire de la composition lipidique des tissues chez les rats traités à l'acrylamide (50mg/kg/jour i.p. pour 10 jours). Le cholestérol hépatique, surtout dans la fraction estérifiée, était diminué chez ces rats; dans cette fraction la proportion de linoléate et de stéarate était diminuée et compensée par une augmentation $d u$ palmitate. Le panicule adipeux s'était considérablement atrophié, entraînant une perte sévère en triglycérides et une augmentation relative de la proportion dans les phospholipides et le cholestérol. Il y avait également une diminution du linoléate, $d u$ palmitate et du palmitoléate dans ce tissu. Au niveau du nerf sciatique, il n'y avait que des modifications mineures dans le profil des acides gras.

From the Clinical Research Institute of Montreal.

Reprint requests for the complete supplement on Friedreich's Ataxia (Phase Three, Part Two) to: Prof. André Barbeau, Clinical Research Institute of Montreal, 110 Pine Avenue West, Montreal, Quebec, Canada, H2W IR7.

\section{INTRODUCTION}

Animals subjected to chronic acrylamide intoxication develop a postural and motor incoordination, and progressive hind-limb ataxia (Kuperman, 1956; Hopkins, 1970). Due to its similarity to the dying back phenomenon in human nervous system, acrylamine-induced neuropathic animals were widely used as an experimental model (Fullerton and Barnes, 1966; Hopkins, 1970). Although extensive studies of the clinical, histological and behavioral features of this neuropathy have been reported (Fullerton, 1969; Spencer and Schaumburg, 1974 a,b; Tilson et al, 1979; Jolicoeur et al, 1979), very little is known about its biochemistry.

Abnormal lipid metabolism has been known to be associated with the development of many neuropathies (Sanbank et al, 1971), such as Refsum's disease (Steinberg, 1972), metachromatic leukodystrophy (Pilz and Muller, 1969), Tangier's disease (Schaffer et al, 1978), multiple sclerosis (Baker et al, 1963; K alofoutis and Jullien, 1974) and Friedreich's Ataxia (Yao et al, 1976; Huang et al, 1978; Davignon et al, 1979). Whether the development of acrylamide-induced neuropathy is associated with an abnormal lipid metabolism is not known. In an attempt to examine this possibility, we have analyzed the tissue lipid of acrylamide-treated rats. This communication constitutes only a preliminary report.

\section{MATERIALS AND METHODS Animals}

Sixteen male Sprague Dawley rats (250-300 g) obtained from Canadian Breeding Laboratories (Montreal) were randomly divided into 2 groups of 8 each. Rats in the experimental group
(A) received a daily intraperitoneal injection of $50 \mathrm{mg} / \mathrm{kg}$ body weight of acrylamide (Bio-Rad Laboratories, Mississauga, Ont.) dissolved in saline for 9 days. The control rats (C) received only saline injections. All animals were maintained on purina rat chow and water ad libitum. At the end of the experimental period, animals were killed by decapitation. Blood was collected from the neck vessel into EDTA containing test tubes. Plasma and red blood cells were separated by centrifugation at $1000 \times \mathrm{g}$ for 10 minutes. Red blood cells were washed twice with $0.9 \% \mathrm{NaC} 1$. Livers and the epididymal fat pads were removed, washed with ice-cold saline, blotted and weighed. In each group, sciatic nerves from 2 or 3 rats were combined into 3 pools and were analyzed.

\section{Lipid Analyses}

Lipids of plasma, red blood cells and of homogenized tissues were extracted with chloroform-methanol, 2:1 (v/v) according to the method of Folch et al, (1957). Total cholesterol (CH) in lipid extracts was measured by gas liquid chromatography (GCL) using 5 cholestane as internal standard. Lipid phosphorus was determined by the method of Bartlett (1959). The aliquots of lipid extracts were fractionated into cholesterol esters (CE), triglycerides (TG) and phospholipids (PL) by thinlayer chromatography (TLC) on silica gel $\mathrm{H}$ (Merck) with a solvent system of hexane-diethyl ether-acetic acid $(90: 10: 1, v / v)$. The chromatograms were visualized by spraying the plate with $0.025 \% 2$ ', 7 '-dichlorofluorescein in ethanol. The lipid bands were scraped into test tubes. Methylation of the fatty acids of each lipid fraction was performed according to Morrison and Smith (1964) using $14 \% \mathrm{BF}_{3}$ - 
methanol (Applied Science, State College, PA). The methyl esters of fatty acids were analyzed by GLC as described previously (Davignon et al, 1979). Individual phospholipid fractions in lipids of red blood cells were further fractionated on TLC developed with chloroform-methanol acetic acidwater, 50:30:8:4 (v/v) (Skipski et al, 1963), and the fatty acid profile determined after methylation.

\section{RESULTS AND DISCUSSION}

The body weights in acrylamidetreated rats decreased rapidly (Figure 1), while the control rats displayed a regular weight increase during the experimental period. The onset of ataxia was rapid and already noticeable after 2 injections. Abnormal behaviors such as postural incoordination and loss of reflexes were also evident in the treated rats. At the time of sacrifice, urinary retention with enlarged bladder was present.

In treated rats, there was no change in liver weight in relation to body size (Table 1) as compared with the controls; but epididymal fat pad weight was significantly decreased ( 0.5 vs 1 $\mathrm{g} / 100 \mathrm{~g} \mathrm{BW}$ in controls). Liver $\mathrm{CH}$ concentrations, mainly in the ester fraction, were decreased $(7.8$ vs $17.1 \%$ in controls). On the other hand, $\mathrm{CH}$ in epididymal fat pad was increased while the proportion of $\mathrm{CH}$ esters remained the same as that of controls. Phospholipid concentrations were found to be decreased in plasma but were significantly increased in epididymal fat pad. The changes in adipose tissue weight and cholesterol and phospholipid contents could be ascribed to lipid depletion of the fat cells through enhanced lipolysis during weight loss. A direct effect of acrylamide on the adipocytes cannot be excluded however.

The fatty acid composition of the 3 major liver lipid fractions are shown in Table 2. The proportions of palmitoleate (16:1) and linoleate (18:2) in liver TG were decreased, whereas those of stearate $(18: 0)$ and arachidonate $(20: 4)$ were increased. The proportions of palmitate $(16: 0)$, oleate (18:1) and docosahexaenoic acid $(22: 6)$ in liver PL were increased, while

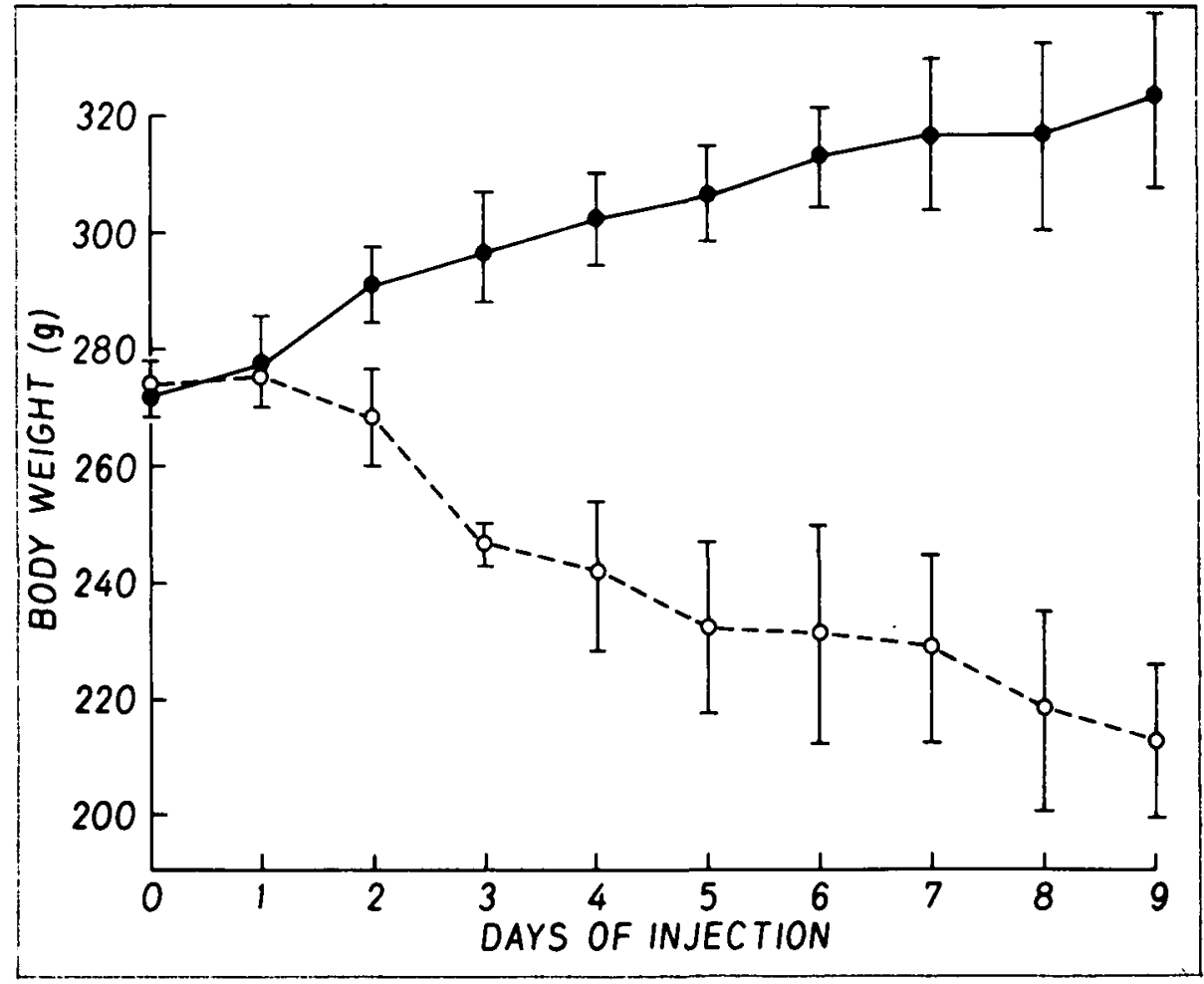

Figure 1 - Effect of acrylamide intoxication on the growth of rats. Body weight (in gram, mean \pm SD) of rats (open circle) receiving acrylamide injection $(50 \mathrm{mg} / \mathrm{kg} /$ day) was significantly $(p<0.01)$ less than that of the controls (closed circle) after 2 days.

TABLE 1: Body and tissue weights, and cholesterol and phospholipid concentration in plasma, red blood cell, 11 ver and epididymal fat pad.

\begin{tabular}{|c|c|c|}
\hline & $\begin{array}{l}\text { Control } \\
(n=8)\end{array}$ & $\begin{array}{l}\text { Experimental } \\
(n=8)\end{array}$ \\
\hline Body Welght (BW, in gram) & $323.1 \pm 15.6$ & $212.5 \pm 13.8^{a}$ \\
\hline Liver Weight ( $\%$ BW) & $2.6 \pm 0.1$ & $2.9 \pm 0.4$ \\
\hline $\begin{array}{c}\text { Epididymal Fat Pad } \\
\text { Welght ( } \% \text { BW) }\end{array}$ & $1.0 \pm 0.1$ & $0.5 \pm 0.3^{a}$ \\
\hline \multicolumn{3}{|l|}{ Cholesterol Concentration } \\
\hline Plasma (mg/dl) & $57.5 \pm 5.9$ & $59.3 \pm 5.5$ \\
\hline Red Blood Cell (mg/ml) & $1.1 \pm 0.2$ & $.1 .2 \pm 0.2$ \\
\hline Liver $(\mathrm{mg} / \mathrm{B})$ & $1.7 \pm 0.3$ & $1.4 \pm 0.3^{\mathrm{d}}$ \\
\hline Epididymal Fat Pad (mg/g) & $0.7 \pm 0.1$ & $1.4 \pm 0.4^{\mathrm{a}}$ \\
\hline \multicolumn{3}{|l|}{ Phospholipid Concentration } \\
\hline Plasma (mg/dl) & $97.8 \pm 12.8$ & $80.7 \pm 4.1^{\mathrm{d}}$ \\
\hline Red Blood Cell $(\mathrm{mg} / \mathrm{ml})$ & $3.2 \pm 0.9$ & $3.5 \pm 0.6$ \\
\hline Liver $(\mathrm{mg} / \mathrm{g})$ & $25.8 \pm 6.5$ & $22.6 \pm 9.9$ \\
\hline Epididymal Fat Pad (mg/g) & $2.0 \pm 0.8$ & $6.7 \pm 1.7^{2}$ \\
\hline $\begin{aligned} & \text { a, a significantly diff } \\
& \text { p }<0.05 \text { respective }\end{aligned}$ & from the con & values at $p<0.001$ and \\
\hline
\end{tabular}


TABIE 2: Major fatty acid composition of liver lipids in control (C) and acrylanideintoxicated rats.

\begin{tabular}{|c|c|c|c|c|c|c|c|}
\hline & $16: 0$ & $16: 1$ & $18: 0$ & $18: 1$ & $18: 2$ & $20: 4$ & $22: 6$ \\
\hline \multicolumn{8}{|c|}{ Triglycerides } \\
\hline C & $\begin{array}{l}24.4 \\
25.4\end{array}$ & $\begin{array}{l}1.5 \\
\underline{0.8} \\
\end{array}$ & $\begin{array}{r}4.2^{\mathrm{b}} \\
\underline{11.2}^{\mathrm{B}}\end{array}$ & $\begin{array}{l}21.6 \\
22.2\end{array}$ & $\begin{array}{l}32.4 \\
22.6^{\mathrm{a}}\end{array}$ & $\begin{array}{l}4.3 \mathrm{~d} \\
\underline{8.6}^{\mathrm{d}}\end{array}$ & $\begin{array}{l}5.8 \\
5.0\end{array}$ \\
\hline \multicolumn{8}{|c|}{ Phospholipids } \\
\hline $\begin{array}{l}\text { C } \\
\text { A }\end{array}$ & $\begin{array}{l}16 . \% \\
18.7\end{array}$ & $\begin{array}{l}0.9 \\
0.9\end{array}$ & $\begin{array}{l}30.8 \\
\underline{27.0^{\circ}}\end{array}$ & $\begin{array}{l}5.3^{3} \\
7.0^{\mathrm{b}}\end{array}$ & $\begin{array}{l}10.5 \\
11.8\end{array}$ & $\begin{array}{l}28.6 \\
26.0^{\mathrm{a}}\end{array}$ & $\begin{array}{l}4.7 \\
6.7^{6}\end{array}$ \\
\hline \multicolumn{8}{|c|}{ Cholesterol Esters } \\
\hline $\begin{array}{l}\mathrm{C} \\
\mathrm{A}\end{array}$ & $\begin{array}{l}13.4 \\
24.4^{d}\end{array}$ & $\begin{array}{l}5.5 \\
6.8\end{array}$ & $\begin{array}{l}41.8 \\
30.2^{\mathrm{d}}\end{array}$ & $\begin{array}{r}12.8 \\
8.4\end{array}$ & $\begin{array}{r}12.0 \\
6.1^{\mathrm{d}}\end{array}$ & $\begin{array}{l}4.7 \\
7.9\end{array}$ & - \\
\hline
\end{tabular}

$a, b, d$ significantly different from the control values at $p<0.001$, $p<0.01$ and $p<0.05$ respectively
TABLE 4: Major fatty acid composition of red blood cell phospholipids in control (C) and acrylamide-intoxicated $(A)$ rats
TABIE 3: Major fatty acid composition of epididymal fat pads of control (c) and acrylanide-intoxicated (A) rats.

\begin{tabular}{rrrrrr}
\hline $16: 0$ & $16: 1$ & $18: 0$ & $18: 1$ & $18: 2$ & $20: 4$ \\
\hline
\end{tabular}

Triglycerides

$\begin{array}{lllllll}\mathrm{C} & 25.8 & 5.9 & 3.9 & 31.9 & 24.6 & 0.6 \\ \mathrm{~A} & \underline{21.6}^{\mathrm{b}} & 2^{3.4^{\mathrm{b}}} & 2.9^{\mathrm{a}} & 39.6^{\mathrm{a}} & \underline{22.9^{\mathrm{d}}} & 0.0\end{array}$

Phospholipids

$\begin{array}{lllllll}\mathrm{C} & 23.8 & 3.0 & 12.9 & 29.5 & 19.5 & 4.5\end{array}$

A $\quad \underline{19.0^{\mathrm{c}}} \quad \underline{1.0}^{\mathrm{b}} \quad{\underline{22.6^{\mathrm{a}}}}^{28.6} \quad{\underline{12.4^{\mathrm{a}}}}^{10.7^{\mathrm{b}}}$

$a ; b, c, d$ significantly different from the control values at $p<0.001$, $p<0.01, p<0.02$ and $p<0.05$ respectively

TABLE 5: Major fatty acid composition of phospholipids and triglycerides extracted from pooled sciatic nerves of control (C) and acrylanide-intoxicated (A) rats

\begin{tabular}{cccccccc}
\hline & $16: 0$ & $16: 1$ & $18: 0$ & $18: 1$ & $18: 2$ & $20: 4$ & $22: 6$ \\
\hline $\begin{array}{c}\text { Phospholipids } \\
\text { C }\end{array}$ & 17.9 & 6.2 & 12.0 & 42.6 & 1.2 & 5.3 & 1.2 \\
A & 18.0 & $2.2^{\mathrm{d}}$ & 13.6 & $\underline{48.6}^{\mathrm{d}}$ & 1.1 & 5.6 & 1.1 \\
Triglycerides & & & & & & & \\
C & 22.2 & 4.6 & 4.6 & 34.8 & 27.6 & 0.5 & - \\
A & ${\underline{14.4^{\mathrm{a}}}}^{2}$ & $\underline{2.0}^{\mathrm{a}}$ & $2.4^{\mathrm{a}}$ & $45.8^{\mathrm{a}}$ & 25.0 & 0.2 & - \\
\hline
\end{tabular}

a, d significantly different different from the control values at $p<0.001$ and $p<0.05$

those of 18:0 and 20:4 were decreased. The proportion of 16:0 in liver CE was increased and this was compensated by a decrease in 18:0 and 18:2.

The fatty acid compositions of epididymal fat pad TG and PL are shown in Table 3. Reduction of the proportions of 16:0,16:1 and 18:2 and increases in 18:0 and 18:1 were found in TG of treated rats compared to those of the controls. A similar pattern was also found in adipose tissue PL but, in contrast, the proportion of 20:4 instead of 18:1 was increased. When the fatty acid patterns of red blood cell major phospholipid fractions were examined, no significant difference between the control and the acrylamide-intoxicated rats was found. (Table 4).
In the sciatic nerve (Table 5), the proportion of 18:1 in PL was increased but 16:1 was decreased. The proportions of 18:0 and 18:1 in TG were both increased at the expense of $16: 0$ and 16:1.

In summary, we have surveyed the effect of acute acrylamide intoxication on blood and tissue lipids in rats. The major changes were found in the epididymal fat pad, the liver and the nerve tissue. Plasma $\mathrm{CH}$ and TG (50.3 vs $49.8 \mathrm{mg} / \mathrm{dl}$ in controls, not shown in the results) were not changed in the acrylamide treated rats, though plasma PL in these animals were decreased. The fatty acid pattern of red blood cell phospholipids usually similar to that of plasma PL was found not to be affected by the drug. These results suggest that acute acrylamide intoxication probably has no direct effect on lipid transport in the circulation. It is not excluded however that the reduction in plasma phospholipid levels might reflect a relative decrease in high density lipoprotein concentration and a redistribution of plasma lipids among the various lipoprotein fractions. It might be worthwhile to study plasma lipoproteins in this model and to examine the effect of this drug administered at a lower dosage and for longer periods of time.

The significant decrease of 18:2 in liver $T G$ and $C E$, and in epididymal fat pad TG and PL is most interesting. As shown in Table 1, liver $\mathrm{CH}$ was decreased in treated rats, and this was mainly at the expense of the CE fraction. The fatty acid pattern of liver CE reveals that the proportion of $18: 2$ was 
decreased in the treated rats. Thus CE appear to be selectively lowered in the liver of treated rats and partly deplected in linoleate by the action of the drug possibly acting at the intestinal wall level.

In epididymal fat pad of treated rats, TG was significantly decreased presumably as a result of enhanced lipolysis; interestingly their proportion of $18: 2$ was also decreased. Thus TG of both liver and adipose tissue were deficient in this essential fatty acid.

A relative deficiency of $18: 2$ in plasma $C E$ has been found in patients with Friedreich's Ataxia (Davignon et al, 1979), though no data are available for the liver $C E$ in these patients. Whether this similarity in 18:2 deficiency between acrylamide-induced ataxia and inherited human ataxia provides an animal model for the study of the development of Friedreich's Ataxia remains to be examined.

\section{REFERENCES}

BAKER, R.W.R., THOMPSON, R.H.S., and ZILKHA, K.J. (1963). Fatty acid composition of brain lecithins in multiple sclerosis. Lancet $1: 26-27$.

BARTLETT, G.R. (1959). Phosphorus assay in column chromatography. J. Biol. Chem. 234: 466-468.

DAVIGNON, J., HUANG, Y.S., WOLF, H.P. and BARBEAU, A. (1979). Fatty acid profile of major lipid classes in plasma lipoproteins of patients with Friedreich's Ataxia. - Demonstration of a low linoleic acid content most evident in the cholesterolester fraction. Can. J. Neurol. Sci. 6: 149156.
FOLCH, J., LEES, $M$. and SLOANE STANLEY, G.H. (1957). A simple method for the isolation and purification of total lipids from animal tissues. J. Biol. Chem. 226: 407-509.

FULLERTON, P.M. (1969). Electrophysiological and histological observations on peripheral nerves in acrylamide poisoning in man. J. Neurol. Neurosurg. Psychiatry 32: 186-192.

FULLERTON, P.M. and BARNES, J.M. (1966). Peripheral neuropathy in rats produced by acrylamide. Brit. J. Industr. Med. 23: 210-221.

HOPKINS, A.P. (1970). The effect of acrylamide on the peripheral nervous system of the baboon. J. Neurol. Neurosurg. Psychiatry 33: 805-816.

HUANG, Y.S., NESTRUCK, A.C., BARBEAU, A., BOUCHARD, J.P. and DAVIGNON, J. (1978). Plasma lipids and lipoproteins in Friedreich's Ataxia. Evidence for an abnormal composition of high density lipoproteins. Can. J. Neurol. Sci. 5: 149-156.

JOLICOEUR, F.B., RONDEAU, D.B., HAMEL, E., BUTTERWORTH, R.F. and BARBEAU, A. (1979). Measurement of ataxia and related neurological signs in the laboratory rat. Can. J. Neurol. Sci. 6: 209215.

KALOFOUTIS, A. and JULLIEN, G. (1974). A study of serum fatty acids in neurological diseases. Biochimie 56: 623-624.

KUPERMAN, A.S. (1958). Effects of acrylamide on the central nervous system of the cat. J. Pharmacol. Exp. Ther. 123: 180192.

MORRISON, W.R. and SMITH, L.M. (1964). Preparation of fatty acid methyl esters and dimethylacetals from lipids in the boron fluoride-methanol. J. Lipid Res. 5: 600-608.

PILZ, H. and MULLER, D. (1969). Studies on adult metachromatic leukodystrophy. Part 2. Biochemical aspects of adult cases of metachromatic leukodystrophy. J. Neurol. Sci. 9: 585 -

SANDBANK, U., BECHAR, $M$. and BORNSTEIN, B. (1971). Hyperlipemic polyneuropathy. Acta Neuopath. 19: 290300.

SCHAFFER, E.J., BLUM, C.B., LEVY, R.I., JENKINS, L.L., ALAUPOVIC, P., FOSTER, D.M. and BREWER, H.B.Jr. (1978). Metabolism of high-density lipoprotein apolipotroteins in Tangier's disease. New Engl. J. Med. 299: 905-910.

SIBURY, J.B. Jr., SMITH, E.K. and HARLAN, W. (1967). An inborn error of short-chain fatty acid metabolism. J. Pediatrics 70: 8-15.

SKIPSKI, V.P., PETERSON, R.F., SANDERS, J. and BARCLAY, M. (1963). Thin-layer chromatography of phospholipids using silica gel without calcium sulfate binder. J. Lipid Res. 4: 227 228.

SPENCER, P.S. and SCHAUMBURG, H.H. (1974a). A review of acrylamide neurotoxicity. Part I. Properties, uses and human exposure. Can. J. Neurol. Sci. 1: 143-150.

SPENCER, P.S. and SCHAUMBURG, H.H. (1974b). A review of acrylamide neurotoxicity. Part II. Experimental animal neurotoxicity and pathologic mechanisms. Can. J. Neurol. Sci. 1: 152-169.

STEINBERG, D. (1972). Phytanic acid storage disease: Refsum's syndrome. In: The Metabolic Basis of Inherited Disease, 4th Edition, (Stanburg, J.B., Wyngaarden, J.B. and Fredricksdon, D.S. Eds.) McGraw-Hill, New York, pp. 688-706.

TILSON, H.A., CABE, P.A. and SPENCER, P.S. (1979). Acrylamide neurotoxicity in rats: a correlated neurobehavioral and pathological study. Neurotoxicology 1: 89104.

YAO, J.K., ELLEFSON, R.D., and DYCK, P.J. (1976). Lipid abnormalities in hereditary neuropathy: Part I. Serum nonpolar lipids. J. Neurol. Sci. 29: 161-175. 